\title{
PRAWA JĘZYKOWE A EMPIRYCZNE UNIWERSALIA JEZZYKOWE
}

\author{
BOGDAN WALCZAK
}

Choć bliskie pojęciu prawa zagadnienie prawidłowości (regularności) w rozwoju językowym pojawiło się w dziejach refleksji nad językiem już w starożytności, w III-II wieku p.n.e., w postaci sporu analogistów (filologów aleksandryjskich) z anomalistami (filozofami ze szkoły stoickiej Chryzypa z Soloi), z których pierwsi, jak wiadomo, byli zwolennikami zbyt wprawdzie rygorystycznie traktowanej i deklarowanej regularności rozwojowej języka, natomiast drudzy protestowali przeciw absolutyzowaniu tej regularności, powołując się na przykład różnych i licznych wyjątków (Milewski, 1976: 31-32), jednak stricto sensu pojęcia prawa głosowego (Lautgesetze) pojawiło się dopiero w siatce pojęciowo-terminologicznej szkoły lipskiej i jej głównego teoretyka, Hermanna Paula. Paul expressis verbis do rangi bezwyjątkowych praw głosowych podniósł ograniczone pod względem czasowym i przestrzennym zmiany językowe (Paul, 1880), odkrywane i formułowane już od czasów Kristiana Raska i Jakuba Grimma oraz jego Deutsche Grammatik (Grimm, 1819-1837), choć ,prawami” nazywane zwykle dopiero później (na przykład o prawie Grimma mówił dopiero w drugiej połowie XIX wieku teoretyk i sanskryto$\log$ Max Müller).

W Encyklopedii językoznawstwa ogólnego, najważniejszym polskim ogólnojęzykoznawczym leksykonie encyklopedycznym, jej redaktor, jeden z najwybitniejszych polskich teoretyków języka, obok tak (tzn. na sposób młodogramatyczny) rozumianych praw językowych $(, \mathrm{P}<$ rawa $>$ jęz<ykowe $>$ różnią się od $\mathrm{p}<$ raw $>$ przyrodniczych tym, że ich działanie jest ograniczone czasem i przestrzenią, tzn., że działają one tylko w określonym czasie i na określonym obszarze" - (Polański, 1993: 419)) obejmuje mianem prawa językowego także regularności uniwersalne, 
właściwe wszystkim językom i wszystkim okresom ich historii: „Językoznawcy podejmowali także próby formułowania $\mathrm{p}<\mathrm{raw}>$, które działają $\mathrm{w}$ jęz $<\mathrm{yku}>\mathrm{zawsze}$ i wszędzie, tzn. niezależnie od czasu i przestrzeni. Przykładem takiego $p<$ rawa $>$ jest $\rightarrow \mathrm{p}<$ rawo $>$ najmniejszego wysiłku" (Polański, 1993: 419).

Expressis verbis, wprowadzając bardzo tu przydatne rozróżnienie terminologiczne między regułą a prawem, pisał na ten temat Witold Mańczak:

Zacząć trzeba od zwrócenia uwagi na fakt, że wielu językoznawców nie zdaje sobie sprawy z fundamentalnej różnicy, jaka zachodzi między prawem a regułą. Reguła dotyczy jednego języka, natomiast prawo odnosi się do wszystkich lub co najmniej większości języków świata. Innymi słowy, reguła do prawa ma się tak jak $1: 3000$, jako że co najmniej tyle ma być języków na kuli ziemskiej ${ }^{1}$. Tak więc można mówić tylko o regule, a nie o prawie Vernera, gdyż ta reguła odnosi się tylko do języka pragermańskiego, natomiast można mówić o prawie rozwoju analogicznego, zgodnie z którym analogia polega daleko częściej na usuwaniu alternacji niż na ich wprowadzaniu, ponieważ prawo to dotyczy wszystkich języków świata. Podobieństwo zaś reguły do prawa polega na tym, że zarówno pojęcie reguły i wyjątku, jak i pojęcie prawa i wyjątku są pojęciami ilościowymi: reguła lub prawo jest tym, co częste, natomiast wyjątek jest tym, co rzadkie. W tym stanie rzeczy statystyka pozwala odróżniać prawa i reguły prawdziwe od fałszywych. Nie brak językoznawców, którzy, formułując reguły lub prawa, poprzestają na zilustrowaniu ich paroma przykładami. Należy z naciskiem podkreślić, że tych reguł i praw nie można uznać za prawdziwe, dopóki się ich nie skonfrontuje ze znacznie większą ilością przykładów i nie ustali się stosunku liczbowego zachodzącego między wypadkami potwierdzającymi daną regułę lub prawo, a wypadkami obalającymi daną regułę lub prawo (Mańczak, 1996: 16-17).

O definicję prawa językowego pokusił się, o ile mi wiadomo jako jedyny w polskiej literaturze przedmiotu, Marek Ruszkowski. Według kieleckiego lingwisty prawo językowe to:

Regularna relacja zachodząca miedzy elementami językowymi, która obejmuje zdecydowaną większość faktów będących przedmiotem obserwacji, która występuje w wielu językach reprezentujących różne rodziny językowe (Ruszkowski, 2010: 18).

\footnotetext{
${ }^{1}$ Jak wynika z tego zdania, Mańczak przyjmuje, że na świecie jest około 3000 języków. Wprawdzie tak właśnie szacuje liczbę języków świata Adam Weinsberg (Weinsberg, 1983: 7, 63), jest to jednak liczba z jednej strony minimalna, a z drugiej - trochę już nieaktualna. Inaczej szacują tę liczbę nowsze opracowania. By się ograniczyć tylko do polskiej literatury przedmiotu: Marian Jurkowski (Jurkowski, 1999: VII) szacuje liczbę języków świata na ponad 8000, Witold Maciejewski (Maciejewski, 1999: 3) na 6000-7000, natomiast Alfred Franciszek Majewicz (Majewicz, 1999: 96) - na około 6500-7000. Majewicz, najlepszy polski znawca zagadnienia, uwzględnia w swojej opinii dane nowych wielkich syntez językoznawstwa porównawczego (Asher, Simpson, 1993; Moseley, Asher, 1994), jego opinia wydaje się więc najbardziej wiarygodna.
} 
$\mathrm{Z}$ drugiej strony należy się przyjrzeć refleksji lingwistycznej na temat uniwersaliów językowych. Wspomniana już Encyklopedia językoznawstwa ogólnego definiuje je bardzo krótko: są to, zdaniem jej redaktora: „Cechy wspólne wszystkim jęz<ykom> świata” (Polański, 1993: 573). Według Polańskiego: „Do u<niwersaliów>, których nikt nie kwestionuje, można zaliczyć takie, jak konwencjonalny charakter jęz<yka>, jego $\rightarrow$ dwuklasowość czy $\rightarrow$ podwójna artykulacja [...]" (Polański, 1993: 573).

Wyszczególnione wyżej cechy języka: konwencjonalność (a ściślej szerzej: arbitralność: wbrew dość rozpowszechnionemu przekonaniu arbitralność i konwencjonalność to bynajmniej nie synonimy), dwuklasowość czy Mairtnetowska double articulation du language wynikają po prostu z jego definicji (kod arbitralny, dwuklasowy, fonemowy). Można więc powiedzieć (co usilnie podkreśla Adam Weinsberg (Weinsberg, 1983: 66-67), który je odróżnia jako uniwersalia definicyjne od właściwych empirycznych), że takie uniwersalia definicyjne rozumieją się same przez się - są konieczne w tym sensie, że kodu, który by ich nie wykazywał, po prostu nie uznamy za język ludzki. Do naszej wiedzy o języku jako takim i o różnych językach świata nic one nie wnoszą. Takim uniwersaliom definicyjnym przeciwstawiają się właściwe, stricto sensu uniwersalia językowe, czyli uniwersalia empiryczne. Nie wynikają one z definicji języka - z punktu widzenia tej definicji mogłoby ich nie być. Do ich sformułowania dochodzimy przez empiryczne badania języków świata².

Gwoli ścisłości należałoby w tym miejscu dodać, że przy formułowaniu uniwersaliów empirycznych bywa też stosowane rozumowanie dedukcyjne. W jego wyniku otrzymuje się tzw. uniwersalia implikacyjne, które za Josephem Greenbergiem (Greenberg, 1966) tak definiuje Kazimierz Polański:

[...] wynikają [one] z innych cech jęz<yka> i które określa się w kategoriach implikacji: jeśli $\mathrm{w}$ danym jęz<yku> występuje cecha $\alpha$, to występuje $\mathrm{w}$ nim także cecha $\beta$. Np. jeśli w jakimś jęz<yku> występuje liczba podwójna, to musi w nim także występować liczba mnoga. [...] Greenberg w swoich rozważaniach o $\mathbf{u}<$ niwersaliach> starał się wykorzystać pojęcie $\rightarrow$ nacechowaności: jeśli w jęz $<y k u>$ wystę-

\footnotetext{
${ }^{2}$ Problemem jest tutaj fakt, że z jednej strony termin uniwersalia zakłada uniwersalność, powszechność, tzn. odniesienie do wszystkich języków świata, z drugiej zaś - nasza znajomość języków świata jest wciąż jeszcze dalece niesatysfakcjonująca. Według Waltera Onga (Ong, 1992) rozwinięte odmiany pisane ma zaledwie 78 języków. Według Alfreda Franciszka Majewicza „,[...] obecnie dla nie więcej niż 5\% języków (ok. 350) istnieje stosunkowo pełny ich opis (słowniki jednojęzyczne i dwustronne dwujęzyczne, gramatyki, podręczniki), dla nie więcej niż 20\% (ok. 1300) języków funkcjonuje opis cząstkowy (np. mały glosariusz, listy wyrazów, opis systemu fonologicznego czy jakiegoś fragmentu struktury morfologicznej itp.), zaś mniej niż 30\% (ok. 2000) języków ma jakąkolwiek dokumentację materiałową (zapisy tekstów). O co najmniej 70\% języków wiadomo niewiele ponad to, że w ogóle istnieją" (Majewicz, 1999: 104). W tej sytuacji świadectwo kilkudziesięciu języków stanowi w praktyce wystarczające potwierdzenie uniwersalności cechy językowej.
} 
puje jakaś kategoria, która jest nacechowana, to jęz $<y k>$ ten posiada także jej odpowiednik nienacechowany. Np. we wszystkich jęz<ykach $>$ występują samogłoski ustne (nienacechowane), natomiast tylko w niektórych samogłoski nosowe (nacechowane), tzn. że jeśli w jakimś jęz $<y k u>$ występują samogłoski nosowe, to jęz<yk $>$ ten musi mieć także samogłoski ustne (Polański, 1993: 573).

Takie uniwersalia implikacyjne można by określić mianem quasi- empirycznych. Jeśli je wyłączymy, tak jak uprzednio wyłączyliśmy uniwersalia definicyjne, pozostaną stricto sensu uniwersalia empiryczne, które można określić jako ustalone na podstawie badań empirycznych możliwie jak największej liczby języków cechy wspólne języków świata. Tu jednak powstaje pytanie, czym takie uniwersalia empiryczne różnią się od praw językowych (uniwersalnych, nie reguł ograniczonych czasem i przestrzenią). Jeśli rzecz rozpatrzyć na przykładzie najlepiej chyba opisanego - w polskiej literaturze naukowej - prawa Behaghla (podobnie jak Witold Mańczak posługuję się formą dopełniacza Behaghla, według wzoru Hegel - Hegla, Schlegel - Schlegla, Wackernagel - Wackernagla itd.), stanowiącego o tym, że szyk równorzędnych (wzajem wobec siebie współrzędnych) członów zdania polega na tym, iż jeśli nie wchodzą w grę względy natury rzeczowej, człon krótszy na ogół poprzedza dłuższy, to znaczy, że mówimy błędy $i$ wypaczenia, dziad $i$ baba, esyfloresy, krótko i węztowato, tad i porządek, ten i tamten, wóz albo przewóz itd., a nie odwrotnie (Behaghel, 1909; Mańczak, 1996: 30; Ruszkowski, 2003; 2015; Walczak, 2017), trzeba stwierdzić, że różnicy nie widać - a w każdym razie ja jej nie widzę. Regularność zaobserwowaną przez Behaghla można, moim zdaniem, równie dobrze (równie zasadnie) określić mianem prawa językowego (powtórzmy jeszcze raz: prawa językowego stricto sensu, nie reguły czy młodogramatycznej Lautgesetze) jak i uznać za jedno z uniwersaliów empirycznych, czyli regularności właściwych teoretycznie - wszystkim językom świata. Należałoby zatem oczekiwać, że ktoś z teoretyków języka albo expressis verbis utożsami prawa językowe z językowymi uniwersaliami empirycznymi, albo jednak wskaże między nimi różnicę, której ja nie widzę. Stan obecny, gdy to samo (moim zdaniem) zjawisko występuje w literaturze naukowej pod dwoma różnymi nazwami, uważam za nieuzasadniony i niepożądany.

\section{Bibliografia}

Asher, R.E. i J.M.Y. Simpson. 1993. The encyclopedia of language and linguistics. Tom 1-10. Oxford: Pergamon Press.

Behaghel, O. 1909. „Beziehungen zwischen Umfang und Reihenfolge von Satzgliedern”. Indogermanische Forschungen 25. 110-142.

Greenberg, J. 1966. Language universals, with special reference to feature hierarchies. The Hague: Mouton.

Grimm, J. 1819-1837. Deutsche Grammatik. Tom 1-4. Göttingen: Dieterich. 
Jurkowski, M. 1999. „Przedmowa”. W zbiorze: Kostrzewski, A. (red.). Wielka encyklopedia geografii świata. Tom XIV. Poznań: Wydawnictwo Kurpisz.

Maciejewski, W. 1999. „Świat języków”. W zbiorze: Kostrzewski, A. (red.). Wielka encyklopedia geografii świata. T. XIV. Poznań: Wydawnictwo Kurpisz.

Majewicz, A.F. 1999. „Języki wymierające i zagrożone - stan i perspektywy”. W zbiorze: Kostrzewski, A. (red.). Wielka encyklopedia geografii świata. T. XIV. Poznań: Wydawnictwo Kurpisz. 95-109.

Mańczak, W. 1996. Problemy językoznawstwa ogólnego. Wrocław-Warszawa-Kraków: Zakład Narodowy im. Ossolińskich.

Milewski, T. 1976. Językoznawstwo. Wyd. 6. Warszawa: Państwowe Wydawnictwo Naukowe.

Milewski, S., Kaczorowska-Bray, K. i B. Kamińska (red.). 2017. Studia logopedyczno-lingwistyczne. Księga jubileuszowa z okazji 70-lecia urodzin Profesora Edwarda Łuczyńskiego. Gdańsk: Harmonia Universalis.

Moseley, Ch. i R.E. Asher. 1994. Atlas of the world's languages. London-New York: Routledge.

Ong, W. 1992. Oralność i piśmienność. Stowo poddane technologii. Przekład: J. Japola. Lublin: Wydawnictwo Naukowe Katolickiego Uniwersytetu Lubelskiego.

Paul, H. 1880. Prinzipien der Sprachgeschichte. Halle: Niemeyer.

Polański, K. (red.). 1993. Encyklopedia językoznawstwa ogólnego. Wrocław-Warszawa-Kraków: Zakład Narodowy im. Ossolińskich.

Ruszkowski, M. 2003. „Prawo językowe Behaghela”. Polonica 22/23. 117-121.

Ruszkowski, M. 2010. „O pojęciu prawo językowe”. Poradnik Językowy. 10. 12-20.

Ruszkowski, M. 2015. „Próba statystycznej weryfikacji prawa językowego Behaghela”. Język Polski. 4. 333-341.

Walczak, B. 2017. „O prawach językowych”. W zbiorze: Milewski, S., Kaczorowska-Bray, K. i B. Kamińska (red.). 391-403.

Weinsberg, A. 1983. Językoznawstwo ogólne. Warszawa: Państwowe Wydawnictwo Naukowe. 